\title{
Innovation risks: challenges and prospects
}

\author{
Nechaev Andrey Sergeevich \\ Department of Industrial Management \\ Institute of Economics, Management and Law \\ Irkutsk National Research Technical University \\ Irkutsk, Russian Federation \\ n-a-s@mail.ru
}

\author{
Ognev Dmitrii Vladimirovich \\ Department of Economics and Management \\ Institute of Economics, Management and Law \\ Irkutsk National Research Technical University \\ Irkutsk, Russian Federation \\ odv1974@rambler.ru
}

\author{
Antipina Oksana Victorovna \\ Department of Economic Theory and Finance \\ Institute of Economics, Management and Law \\ Irkutsk National Research Technical University \\ Irkutsk, Russian Federation \\ antipina_oksana@mail.ru
}

\begin{abstract}
Innovation risk is a complex multidimensional concept. To function successfully in a risk sphere, employees should have expert knowledge in economics. Effective risk management contributes to the competitiveness of a company on the domestic and international markets and increases the economic and industrial potential required for implementation of the state innovative development strategy as a whole. Innovation performance indices are the ability of operational risk management, the ability to predict innovation risks. Entrepreneurs play a coordinating role in the movement of risk management and their combinations. As a result, entrepreneurs help to establish a hierarchy of innovative connections in the real economy and economic system as a whole. The article describes the classification of risks. The article analyzes risk management methods applied in the innovation sector. It also deals with the issues of risk effects.
\end{abstract} risks

Keywords-economic growth, enterprises, innovative activity,

\section{INTRODUCTION}

For the Russian Federation, the problems connected with the successful implementation of innovative projects are extremely topical, taking into consideration the increasing technological degradation of manufacturing industries. Even large-scale investment in old manufacturing industries cannot bring proportional return but causes cost inflation. Thereupon, development and implementation of innovative projects will allow Russia to reduce the dependence on raw materials exportation, modernize the economy and create competitive advantages on the global market. It will improve the citizen's life quality.

In Russia, researches on formation and development of the innovative system began in the second half of the 1990s. In Russia, innovation system formation aims at maintaining sustainable development of the national economy and improving citizens' life quality based on the use of mental potential, generation, distribution and implementation of new knowledge.

The practice showed that Russian regions survive owing to federal grants, natural resources and available industrial potential which cannot provide complex regional development and improvement of life quality. Innovation development could solve these problems. Since the last century, in Great Britain, Germany, the USA and other nations, regional authorities along with federal governments have been playing an important role in the development of high technology industries and innovative activities.

There are examples of fast and successful innovative development of local territories. Originally, campuses played a role of research and technology (Oxford, Cambridge) and industrial centers (Lyons). Later on technological areas (Karlsruhe) and research-production clusters were established (Silicon Valley, the Carolina triangle, Highway 128). Today the most widespread organizational elements of the innovative infrastructure integrating science and manufacture are research technological parks (San Antonio, Texas).

Analysis of researches showed that innovative development takes place only in some territories possessing the high innovative potential and located mainly in the western Russian regions. For example, in 2009, in Russia there were more than 60 research towns distributed throughout the Russia's territory. Most of them were located in the Central District (37 territories), Siberian District (11 territories) and Ural District (10 territories) [6].

The economic transition of a country towards the innovative way of development is impossible without the formation of a competitive, global, national innovation system. In accordance with the best international practices, effective national innovation system formation is a result of systematic innovative activities and technological development encouragement in economic sectors, as well as 
elimination of fragmentation of the existing innovation system.

Nowadays the strategic nature of the task to turn Russia into an innovative economy is defined in legislatiion, programs and standards It is actively debated by researchers and general public. In Russian regions, the regulatory legal acts are being developed and adopted to stimulate innovative activities.

Last year, considerable reduction of expenses on technological reequipment of industrial enterprises caused basic changes in capital assets which are outdated and wornout. Investment in fixed asset updating is an obligatory condition for overcoming recession of production volumes in Russian industries which took place for several years of the economic reforms. Most Russian researchers pay attention to the insufficiency of investment as one of the main causes of catastrophic deterioration of basic production assets and lack of progress.

According to the statistics, investment in innovative projects is not appreciable.

During the years of the market economy in Russia, the innovative sector has slightly increased. Innovative production in Russia makes nearby 1 percent. In Finland, for example, this index is more than 30 percent. In Italy, Portugal, Spain, it amounts to 1020 percent. The issue of investment and innovation development is especially topical for Russian enterprises as the market of capital in Russia is still insufficiently developed.

Financing of innovative activities is carried out mainly due to internal resources of enterprises which are often insufficient. The main financing source for innovative enterprises is equity capital: 74 percent of the enterprises use their own capital plus investment, 50 percent of the enterprises use direct investment and financing of specific projects of customers. 28 percent of enterprises use bank credits, 14 percent - loans and venture investment and financial resources [2].

So, the innovative economy can exist only in countries and regions which are able to implement innovation projects. Thus, the authors suggest considering the transition to a qualitatively new stage of development not only at federal and regional levels but at the municipal level. Municipal territories are basic territorial management links in which all basic processes of the population occur. Among them, one can mention

- production and social consumption,

- reproduction

- staff training,

- daily process management,

- consumer market development,

- new market development,

- territorial infrastructure development,

- self-development and self-management.
It is generally accepted that the mankind passed through two historical phases of economic development - agrarian and industrial ones. Since the last decade of the XX century, it has been experiencing the third phase - post-industrial - which can be characterized as "new economy" or "knowledge economy" or "innovation economy." The conceptual frameworks for innovations with regard to economic and social relations were studied and specified by M. Bacior [1], L. Oulasvirta [11], A.V. Prokopyeva [12], A.S. Nechaev [10].

Innovation risks have been studied by many researchers. For example, A.V. Prokopyeva studied risk effects on innovation processes [12].

Innovation performance indices are used to assess the ability to predict innovation risks. Entrepreneurs play a coordinating role in risk management. They help establish a hierarchy of innovative relations in the real economy and economic system as a whole.

Risk is an universal concept. Each social development stage faced challenges in innovative activities. Economic efficiency depends on qualitative characteristics of innovation risks.

Innovation risks as a complex concept are studied by a number of disciplines - innovation management, risk management, psychology, etc. The issue of risk identification is dealt with in many researches.

It should be noted that innovation and risk management issues are studied since school years. The education system meets social needs.

\section{METHODOLOGY}

At present, innovation activities play a key role in ensuring the competitiveness of any economy, improving living standards, and contributing to the growth of people's welfare. Efficient government regulation and business support systems are one of the priority factors for successful innovative development.

The authors have already dealt with relationship between national innovation performance expressed in the Global Innovation Index, and tax burden rate (direct and indirect taxes) for businesses and individuals, and between the amount of direct investment and production activity index. To improve innovation performance of businesses, some methods for modernizing the fiscal policy (budget, leasing, amortization, investment, tax, customs, monetary, investment tax credit and tax credit application policy) by amending regulatory legal acts were developed.

The key role of innovation activities, innovation intensification, and innovation performance improvement are the leading features of the modern economy. Taxation is one of the most efficient tools of the government regulation in the national economy and international economic processes.

Economic integration and international trade expansion are key factors contributing to specialization intensification and production cooperation on the global market. 
Therefore, the issue of risk effects on the economy is crucial for ensuring economic growth within the economic unions and improving economic relationship of nations.

Assessment of innovation risks and identification of risk effects on the economic situation of enterprises is a difficult multipurpose task. The existing risk minimization matrices cannot allocate the most dangerous risks in order to make prompt effective administrative decisions. There is no risk management algorithm to minimize and neutralize innovation risks $[1,2]$.

First, risk analysis showed that the amount of risks depends on the organizational structure (the more departments the enterprise has, the more diversified risks are). Second, it is necessary to specify a risk group or subgroup. Third, it was noted that some researchers only classify risks specifying their relation to other groups of risks.

\section{RESULTS}

A risk innovation project is the most dangerous project. Innovation projects have certain life cycles.

Challenges of innovation risk prediction cause project uncertainty. Any invention involves some rejection risks. It requires analyzing different classifications of risks for innovation projects.

Risks of innovation projects can be divided into the following ones:

- Imperfect legislation, low level of insurance, noncompliance with standards, price risk, organizational risk.

These risks are typical for innovative activities. Inadequate legislation causes differences between public services and innovative businesses.

The low insurance level causes a number of force majeure situations. All participants may suffer significant losses.

Standardization as current social requirement. Adherence to rules and regulations is paramount.

Price risks are caused by a number of factors. They can be identified in time and neutralized.

Organizational risks are connected with planning, organization, staff motivation and supervision. The issue of organization risks is often under discussion.

Project implementation involves various stages and risks.

Project managers should always develop investment plans for innovation projects [13].

The production stage is epy hardest and time consuming. At this stage, a large number of errors occur due to the lack of expertise in technology applied, inadequate materials selected, or lack of loans. A blame game is also typical for that stage.

The final stage involves auditing of financial documents of customers and contractors. At this stage, a risk of lacking invoices occurs.
Innovative activities are connected with a high degree of uncertainty: they can cause failure and bankruptcy. But innovative activities change technical and manufacturing processes, increase profits of businesses.

\section{A. Analysis of t existing assessment methods}

Now one of the major theoretical and practical issues is ensuring financial stability of businesses. Development of market relations, competition strengthening make managers improve innovative activities and provide high competitiveness in Russia and on the world market. Investment improves innovation performance of businesses.

Analysis of the economic methods of fixed capital reproduction helps conclude that slow innovative development is due to drawbacks of the risk management system.

Analysis carried out by modern Russian and foreign economic researchers showed that there is no uniform approach to innovation risk management.

Innovation risk classification could help identify characteristics of risks, their types, understand their nature.

All innovation risks can be grouped according to their characteristics: labor, administrative, financial, industrial, infrastructural and economic. The groups of risks are allocated for each potential in each type and subtype [5, 8].

Besides, innovation risk classification aims at analyzing and making conclusions on project prospects and management efficiency.

New approaches to innovation risk management are required due to the fact that the main financial sources of innovative business are their internal resources and innovation projects are rather risky.

\section{B. Uniform classification of innovation activities of businesses}

Development of the uniform risk classification for innovative businesses is required to determine characteristics of risks and efficient risk management tools aimed at minimizing and neutralizing innovation risks for businesses (Table 1).

The classification shows that all innovation risks are grouped according to their potentials: labor, administrative, financial, industrial, infrastructural and economic. The groups of risks are allocated for each potential in each type and subtype. 
TABLE I.

UNIFORM CLASSIFICATION OF INNOVATION RISKS FOR BUSINESSES

\begin{tabular}{|c|c|}
\hline Type & Subtype \\
\hline & Group : Social \\
\hline \multirow{3}{*}{ Labor } & Qualified staff selection \\
\hline & Low level of salaries \\
\hline & Variability of staff structure \\
\hline \multicolumn{2}{|r|}{ Group : Business } \\
\hline Constant & $\begin{array}{llll}\begin{array}{l}\text { Adverse short-term fluctuation of international } \\
\text { currencies }\end{array} & & \\
\end{array}$ \\
\hline $\begin{array}{c}\text { Penalty } \\
\text { payment risk }\end{array}$ & Non-payment risk due to the imperfect legal system \\
\hline \multicolumn{2}{|r|}{ Group : Currency } \\
\hline The advance & Asset retention risk \\
\hline \multicolumn{2}{|r|}{ Group : eCONOMIC } \\
\hline Situational & Change of the economic situation \\
\hline \multirow{2}{*}{ Competitive } & Profit decrease risk \\
\hline & Facilities operation risk \\
\hline \multicolumn{2}{|r|}{ Group : Property } \\
\hline \multirow{2}{*}{$\begin{array}{l}\text { Property loss } \\
\text { risk }\end{array}$} & Property loss risk due to natural factors \\
\hline & Property loss risk due to anthropogenic factors \\
\hline
\end{tabular}

a. Made by the authors

\section{Calculation methods for risk effects on business activities}

Damages due to risks should be calculated. But calculation methods have not been yet developed. The authors suggest a method for calculating the amount of damages [4,7].

1. Administrative efficiency factor is calculated as the relation of risks expenses of the administrative potential to the innovation project implementation duration:

$$
K_{i}=\sum \frac{r_{i}}{t_{i}}=\frac{r_{\text {per }}}{t_{\text {per }}}+\frac{r_{\text {tem }}}{t_{\text {tem }}}+\frac{r_{\text {pros }}}{t_{\text {pros }}}+\frac{r_{\text {ong }}}{t_{\text {ong }}}
$$

where $\mathrm{Ki}$ is the administrative efficiency factor;

$r_{p}$ er is the expenses caused by business risks; $r_{\text {tem }}$ is the expenses caused by uncontrollability risks ; $r_{\text {pros }}$ is the expenses caused by uncontrollability project risks; $r_{\text {ong }}$ is the expenses caused by specific risks;

tper - tong -administrative risk situation duration.

The administrative efficiency factor establishes the sum of risk elimination tools for a definite time interval.

2. Labor efficiency factor is calculated as the relation of the expenses of labor risks to the innovation project implementation duration:

$$
K_{t}=\frac{r_{\cos }}{t_{\cos }}
$$

where Kt is the labor efficiency factor;

$r_{c o s}$ is the expenses due to labor risks;

\section{$\mathrm{t}_{\cos }$ is labor risk situation duration.}

The labor efficiency factor establishes the tools for minimizing risks during innovation project implementation.

3. Financial efficiency factor is calculated as the relation of innovation risks expenses of the financial potential to the innovation project implementation duration:

$$
K_{f}=\sum \frac{r_{f}}{t_{f}}=\frac{r_{a}}{t_{a}}+\frac{r_{a d}}{t_{a d}}+\frac{r_{b}}{t_{b}}+\frac{r_{e}}{t_{e}}+\frac{r_{b k}}{t_{b k}}
$$

where $\mathrm{K}$ is the financial efficiency factor;

$r_{a}$ is the expenses due to currency risks; $r_{a d}$ is the expenses due to speculative risks; $r_{b}$ is the expenses due to insolvency claims risks; $r_{e}$ is the expenses due to settlement risks; $r_{b k}$ is the expenses due to financial and economic risks;

ta - tbk - finacial risk situation duration.

The financial efficiency factor establishes the sum of risk elimination during innovation project implementation.

The general efficiency factor establishes a total amount of risk elimination tools for a certain time period.

First, our method is used to calculate possible innovation risks, neutralize them and create such industrial and economic conditions in which innovation risk occurrence will be minimum. Second, the method is based on the relationship of expenses caused by innovation risks and risk situation duration. Third, it allows applying the universal coverage connected with losses for a specific period of time. Fourth, the situations management sum connected with the risk occurrence is calculated while planning the enterprise budget.

As a whole, the developed factors are taken into account when calculating the sum required for situations connected with unforeseen loss risks danger, profit or income short-reception due to economic changes or adverse circumstances from idea development to manufacture of an innovative product.

First, the method is used to calculate resources for elimination of administrative, labor, financial infrastructural, industrial, and economic risks occurring during innovation project implementation. Second, the method saves time at a risk management stage and neutralizes and minimizes risks.

Considering that the key resource of innovative businesses is their internal funds and taking in account the risky nature of innovation projects, development of a new method for innovation risk management is required.

\section{DISCUSSION}

The issues of successful innovation project implementation are very urgent for Russia experiencing technological degradation. Even the most scaled investments in worn-out technological systems cannot bring the proportional return and cause costs inflation growth. Thereupon innovative projects will allow Russia to reduce the existing raw materials dependence, modernize the economy and create the competitive advantages on the international level in order to stimulate increase in citizen's living standards and life quality. 
It is generally recognized that the economic growth based only on the raw materials export cannot be stable for a long time and financing of innovative businesses is especially urgent. It is necessary to carry out the transition to innovative development to provide higher and steady rates of the economic growth and encourage development of hi-tech industries.

At the same time, it does not mean the automatic shutdown of raw materials extraction since raw materials are the basis of both Russia's and world economies. Future national development should aim at accelerated rates of innovative technology development.

As a rule, innovative activities are characterized by the uncertainty and a high degree of risks. Therefore, financial support for innovative businesses should be based on such principles as diversity, flexibility and adaptability to changes of innovative processes. It will contribute to fast and effective implementation of innovations with their further commercialization ensuring investment return growth. It assumes the formation of the financial support system for innovation activities based on the combination of budgetary and off-budget components. Internal sources mobilization for financing innovative businesses in Russia is also important.

Currently, the government presented by various institutes and private sector representatives (pension funds, insurance companies, credit organizations) possesses the most powerful financial possibilities which are uninvolved in the innovative process. However they are able to strengthen innovative accents during innovation project implementation and promote transformation of innovations into one of the economic growth factors [3].

The high innovation risk level requires diverse financial sources for innovation activities. In Russia, such financial resources for innovation businesses are used as follows:

- budgetary subsidies,

- special off-budget funds for R\&D activities,

- internal resources of enterprises,

- resources of commercial financial organizations,

- credit resources of investment banks authorized by the government,

- foreign investment,

- resources of national and foreign research funds,

- savings of individuals.

These financial resources are direct financial support. Besides, the enterprise can use indirect financial support (tax planning instruments for saving money and financing innovative activities). Among the various innovation forms of financing innovative activities, credit tools are of special significance [15].

It should be noted that the current stage of Russia's economy modernization requires considerable investment not only for traditional sectors but for innovative projects as well. Meanwhile, there is still no effective mechanism to stimulate the expansion of innovative activities. Significant investment in innovative project implementation will turn Russia into an innovative economy.

As far as internal resources of enterprises are a key source of financial support for innovative activities and innovative activities require greater amount of financial resources, it is necessary to develop new approaches to solve the problem of financial resources consolidation and use them for innovative activities. The current situation with financial support for innovative activities is characterized by an extremely low level of investment in innovative businesses.

\section{CONCLUSION}

Innovation risk is a complex concept. Employees should have economic expertise to function successfully in a risk sphere. The research topicality is due to the need for innovation risk identification and management, formation of favorable economic and industrial environment which will help Russia become an innovative economy.

The value of innovation risk management is increasing as it influences the economic efficiency of businesses, boosts its competitiveness on the domestic and international markets, and increases the economic and industrial capacities required for innovation development strategy implementation.

As a rule, innovation risks are analyzed within different conceptual approaches. As a result, one can observe a number of theories where risks are characterized by different characteristics. There is no uniform classification required to reveal the nature of risks, relations and dependences connected with risks. It prevents efficient innovation risk management $[14,16]$.

Besides, it is necessary to emphasize that there is no uniform technique for innovation risk effects assessment. Each company applies independently developed methods of risk calculation based on their general model developed on the relation of risk-related expenses to the duration of project implementation. It causes cost assessment errors of the revealed risks and their negative consequences and decreasing management efficiency.

The developed algorithm includes the most significant stages of innovation risk management control and aims at reducing innovation risks. The novelty of the algorithm is due to the consecutive involvement of risk management methods in innovative activities of businesses.

The main problems in innovation development are: risks, high cost of innovation projects, long-term return on innovation. At the same time, the economic efficiency depends on the results of risk management innovation activities of enterprises.

Use of innovation risk assessment techniques enables companies to create tools for quality risk analysis in order to neutralize possible risks for innovative activities.

Thus, formation of new mechanisms, contributing to risk minimization, use of additional resources for innovative 
activities, innovation risk management are urgent issues of the modern stage of Russia' economic development.

\section{Acknowledgment}

The authors acknowledge receiving support from statefunded research program of Irkutsk National Research Technical University. We are responsible for all errors as well as heavy style of the manuscript.

\section{References}

[1] M. Bacior, "Technological Innovation in the Context of Company Operation Risk", Journal of Konbin, vol. 33, pp. 251-260, 2015.

[2] T.Boshkov, "Creating successful management through risk exposure detection and access to finance of the company", Quality - Access to Success, vol. 18, pp. 116-118, 2017

[3] Q.-A Chen, F. Du, "Financial innovation, systematic risk and commercial banks' stability in China: theory and evidence", Applied Economics, vol. 48, pp. 3887-3898, 2016.

[4] E.M. Grochowski, J. Warschat, R. Dasher, "The impact of collaboration with big companies on entrepreneurial technology innovation", Conference on Management of Engineering and Technology, pp. 410419, September 2016 [Portland International Conference on Management of Engineering and Technology: Technology Management For Social Innovation, Proceedings, p. 754, 2016].

[5] O. Guillaume, N. Lot, "Risk management and social innovation: The example of the outage organization in a high risk industry", Risk, Reliability and Safety: Innovating Theory and Practice, p. 77, September 2016 [Proceedings of the 26th European Safety and Reliability Conference, p. 115, 2017].

[6] T. Hu, C. Xie, "Competition, Innovation, Risk-Taking, and Profitability in the Chinese Banking Sector: An Empirical Analysis Based on Structural Equation Modeling", Discrete Dynamics in Nature and Society, vol. 1, pp. 42-46, 2016.
[7] K. Kluza, "Financial innovation in local governments as a response to the deterioration of their risk profile and legislative changes: The case of Poland", Innovation Journal, vol. 21, pp. 21-25, 2016.

[8] T. Koc, E. Bozdag, "Measuring the degree of novelty of innovation based on Porter's value chain approach, European Journal of Operational Research", vol. 257, pp: 559-567, 2017.

[9] M. Mukherjee, A. Singh, A. Žaldokas, "Do corporate taxes hinder innovation?" Journal of Financial Economics, vol. 124, pp: 195 221, 2017.

[10] A.S. Nechaev, O.V. Antipina , A.V. Prokopyeva, "The risks of innovation activities in enterprises", Life Science Journal, vol. 11, pp. 112-117, 2014.

[11] L. Oulasvirta, A.-V. Anttiroiko, "Adoption of comprehensive risk management in local government", Local Government Studies,vol. 43, pp. 451-474, 2017.

[12] A.V. Prokopyeva, A.S. Nechaev, "Key features of risks of company innovative activities", Middle East Journal of Scientific Research, vol. 17 (2), pp. 233-236, 2013

[13] B. Stosic, M. Mihic, R. Milutinovic, S. Isljamovic, "Risk identification in product innovation projects: new perspectives and lessons learned", Technology Analysis and Strategic Management, vol. 29, pp. 133-148, 2017.

[14] D. Teece, M. Peteraf, S. Leih, "Dynamic capabilities and organizational agility: risk, uncertainty, and strategy in the innovation economy", California Management Review, vol. 58, pp. 13-35, 2016.

[15] N.A. Torugsa, A. Arundel, "Rethinking the effect of risk aversion on the benefits of service innovations in public administration agencies", Research Policy, vol. 46, pp. 900-910, 2017.

[16] M. Weimer, L. Marin, "The role of law in managing the tension between risk and innovation: introduction to the special issue on regulating new and emerging technologies", European Journal of Risk Regulation, vol. 7, pp. 469-474, 2016. 